\title{
Research on Chinese Culture Aphasia in College English Teaching and Countermeasures
}

\author{
PENG Hong-li \\ Leshan Normal University, Sichuan, China
}

\begin{abstract}
With the realization of globalization, intercultural communication has grown in significance. However, some Chinese scholars in foreign language education field have noticed a disappointing phenomenon-Chinese culture aphasia during intercultural communication. This paper will discuss the relationship between culture and language and reveal that it is important to introduce Chinese culture to the outside world so as to have effective and harmonious communication. Based on this theoretical framework, this thesis analyzes the phenomenon of the Chinese culture aphasia in current college English teaching and proposes solutions to the problem.
\end{abstract}

Keywords: culture and language, college English teaching, Chinese culture, countermeasures

\section{Introduction}

With the development of new science and technology, the realization of globalization, and especially the implementation of the "One Belt, One Road" policy, intercultural communication has become more and more significant and frequent between China and other countries. However, in the course of intercultural communication, the phenomenon of "Chinese culture aphasia" has emerged, which has become a source of intercultural miscommunication, and worse still, damaged China's reputation in international affairs. Therefore, it is matter of utmost urgency to introduce Chinese culture to the outside world for the sake of harmonious intercultural communication.

To reach that goal, it is indispensable to introduce Chinese culture into college English teaching. English is increasingly acknowledged as a lingua franca all over the world, so it is the appropriate language to be employed when Chinese culture is introduced to the outside world. However, the necessity of introducing Chinese culture into college English teaching curriculum has not been adequately taken into account. What is more, the current college English syllabus, textbooks, teaching materials, teachers, and teaching methods are incapable of satisfying the demand of Chinese cultural teaching and learning. The consequence is that college students are incapable of expressing Chinese culture in English. In order to improve the students' intercultural communicative competence, it is necessary to introduce Chinese culture into college English teaching.

\section{The Relationship of Culture and Language}

Culture defies any perspective definitions as it is a complex matrix of interaction elements. Culture is

PENG Hong-li, associate professor, M.A., College of Foreign Languages, Leshan Normal University, Sichuan, China. 
omnipresent, multidimensional, complex, and all-pervasive. These characteristics of culture led Hall (1977) to conclude that "there is not one aspect of human life that is not couched and altered by culture" (p. 14). It is true that culture is everything and everywhere. Because it is so broad, there is not a single definition or central theory of what it is. In fact, some people have collected more than 200 definitions. For the purpose of this thesis paper, the author prefers to take the definition provided by Samovar, Porter, and Stefani:

Culture refers to the deposit of knowledge, experience, beliefs, values, attitudes, meanings, hierarchies, religion, notions of time, roles, spatial relations, concepts of the universe, and material objects and possessions acquired by a group of people in the course of generations through individual and group striving. (Samovar, Porter, \& Stefani, 1998, p. 36)

It is universally acknowledged that language and culture are closely related to each other. On the one hand, language is a part of culture and plays a very important role in it. It is considered to be the keystone of culture, the primary vehicle by which culture transmits its beliefs, values, and norms. On the other hand, language is also influenced and shaped by culture; it reflects culture. That is to say, culture is one of the most important attributes of language and exerts great influence on language. Sapir-Whorf (1956) cited a number of examples to support this idea. For instance, English has three separate words for "insect", "aeroplane", and "pilot", but the Hopi Indian language has only one. Eskimo abounds in vocabulary for describing different kinds of "snow", whereas English has only two words. Just as Kramsch (2000) stated in her book, Language and Culture, "Language expresses cultural reality......embodies cultural reality.......and symbolizes cultural reality" (p. 3). Without language, culture would not be possible.

The link between culture and communication is also significant to the understanding of intercultural communication because it is through the influence of culture that people learn to communicate. It is communication that links us to our world. When culture differs, communication practices also differ. Culture gives meaning for communication and communication allows us to act out our cultural values and to share our language and our culture. Just as Samovar and Porter (2007) pointed out: “...culture and communication work in tandem - they are inseparable. In fact, it is often difficult to decide which is the voice and which is the echo" (p. $8)$.

In a nutshell, language and culture are intertwined and are shaping each other. It is impossible to separate the two, as they are inextricably related to such an extent that people cannot understand or appreciate one without knowledge of the other. If we select language without being aware of the cultural implications, we may at best not communicate well and at worst send the wrong message. Therefore, language learning is also culture learning, and thus language and culture should be taught simultaneously in foreign language teaching. Needless to say, college English teaching has the responsibility to bring about renaissance in terms of native language and culture, and at the same time, promotes in college students' intercultural communicative competence.

\section{The Present Situation of Chinese Culture Teaching in College English Teaching}

However, research on the importance of culture in college English teaching started late in China. It was not until 1980s that scholars in China noticed the function of culture in foreign language teaching and learning. And not until 2007, when the Chinese Ministry of Education issued College English Curriculum Requirements (Requirements hereinafter), was culture incorporated into the guidelines for English instruction to non-English major students. The Requirements emphasized that the objective of college English teaching was "to develop 
college students' ability to use English in an all-round way, ... and at the same time they will be able to enhance their ability to study independently and improve their cultural quality so as to meet the needs of China's social development and international exchanges".

For the first time, the Requirements stated "cultural quality". However, cultural quality should include both English culture and Chinese culture for the sake of reaching harmonious intercultural communication. The Requirements indicated the importance of integrating Chinese culture into college English teaching.

Never-the-less, the reality is that there still exists the phenomenon of "Chinese Culture Aphasia" in college English teaching. In the past decades, college English teaching has attached great importance to the introduction of English culture and Western traditional ideology and customs while ignoring the Chinese culture. What is more, college English teaching syllabus, teaching materials, and tests did not reflect Chinese culture even though distinguishing the differences between Chinese and Western culture is of great significance to English teaching and learning. Despite the fact that Chinese culture is designed to be the contents of the translation passage of the nationwide College English Test-4/6, it is still not sufficient to attract extensive attention. CHEN, LI, and LIU (2005) pointed out:

Many scholars of intercultural communication seem to like only one side of a coin-They have concerned themselves with communicator's ability to empathize and understand the target culture and language and its people, but little remarks have been made about the necessity of promoting learner's positive motivation and attitude toward their native language, people and culture. (CHEN, LI, \& LIU, 2005, p. 256)

When too much emphasis is placed on the teaching of Western culture, it certainly results in Chinese Culture Aphasia. Consequently, for foreign language learners in China, "it is not the superficial but the profound part of culture that has become the major obstacle to developing their intercultural communicative competence" (CONG, 2000).

The above mentioned phenomenon has caused college students' failure in expressing the Chinese culture in English. Many students can talk about the Western festivals, such as Christmas, Halloween, Valentines Day, etc., in fluent English, while having no idea about how to convey the history and importance of traditional Chinese festivals, such as Spring Festival, Tomb-sweeping Day, Dragon Boat Festival, and Mid-Autumn Festival. The depth of this problem should not be underestimated. Students often fail to convey facts correctly, such as when a holiday (e.g., Dragon Boat Festival) is celebrated. Simple references to the lunar calendar are omitted leaving many foreigners with the false understanding that May 5th (solar calendar) is the date when we remember QU Yuan. If basic factual detail is omitted or mis-communicated, how can we expect more complex aspects of Chinese culture, such as the symbolism of eating Zongzi or the important role that food plays in our society, to be expressed adequately? How can we expect the university students to explain our history, philosophy, and the long-standing Chinese values and morality in English correctly?

Moreover, one of the goals of college English teaching is to promote the dissemination of Chinese culture all over the world. As English language is playing a dominant role in international communication, it seems self-evident that English should be taught as an international language in China. And for a long time, college English education in China has placed emphasis only on learning English culture and ignored the introduction of native culture because "Either the policymakers of foreign language education syllabus or foreign language educators are lack of sufficient knowledge of the important role of Chinese language and culture in foreign 
language teaching" (WU, 2006). CONG (2000) pointed out, "If, the lack of Western culture in previous English teaching has led to multidimensional communication barriers in international communication (mainly "understanding barriers"), then the negative impact of the Chinese culture aphasia in English teaching on international communication is more severe".

The phenomenon of Chinese culture aphasia in college English teaching has finally drawn the attention of some researchers in China. CUI (2009), JIA (2015), MAO (2014), and J. WANG, FU, H. WANG, and ZHAO (2016), all explored the phenomenon of Chinese culture aphasia in theory, discussed its causes, and proposed related countermeasures. However, ZHANG Wei-min and ZHU Hong-mei (2002) conducted an empirical research on 126 non-English majors in Tsinghua University. They carried out a test of Chinese culture covering Chinese traditional food, places of interest or historical sites, as well as folk customs. Their research result showed that the vast majority of university students are incapable of expressing Chinese culture in English.

In order to confirm their research results, the author conducted the same test. Considering the English level of our students in a local normal university, the author made some slight changes of the test questions devised by ZHANG Wei-min and ZHU Hong-mei. With this revised version, the author tested 115 students selected from both the College of Political Science and the College of Chemistry of Leshan Normal University.

There are three areas of cultural testing, including food, folk culture, and famous scenic spots or historic sites. The food part is composed of two sections. In section one, students were required to translate eight snack food from Chinese into English. Of the 115 students, only two students (1.74\%) correctly translated four snacks; six students (5.22\%) obtained three correct answers; 49 students (42.61\%) had two correct answers, 47 students (40.87\%) provided only one correct answer; and the remaining 11 students $(9.56 \%)$ failed to translate any snack words correctly. In the second section, food items were taken from a traditional Chinese menu. Students were required to translate five traditional Chinese dishes into English. In this section, only 12 students (10.43\%) got even one item correct and the rest of the students had no correct answers.

The next part, Chinese folk culture, required students to introduce the Mid-Autumn Festival because it was approaching. Only 39 students could write the festival correctly in English. However, only 30 out of the 39 could write two or three sentences to make a simple introduction of this festival, which accounts for $26.08 \%$. The vast majority of the students did not answer. The last part of the test was introducing a Chinese historic place or scenic spot, the readable copies were only 28 , accounting for $24.35 \%$.

Evaluation of the test results supported several conclusions. Firstly, the test results demonstrated that most students were unable to express Chinese culture in English. Only one student used the word "lunar" to indicate the date of the Mid-Autumn Festival. To some extent, it can be said that the students do not know how to express unique Chinese cultural phenomena events in English. Secondly, the students of Liberal Arts did a better job than those of Science. And those who had passed the CET-4 had a better performance. In a word, from the test results we can safely conclude that university students are apparently lacking sufficient knowledge of both Chinese culture and the English skills needed to express Chinese culture. This will definitely result in continued "Chinese Culture Aphasia" in intercultural communication.

\section{Countermeasures}

In order to change the status quo of the "Chinese Culture Aphasia" in the present college English teaching, 
effective measures should be adopted.

First of all, the policymakers should pay more attention to this issue. Although the existing teaching syllabus, to some extent, reflects the importance of cultural factors, Chinese culture has never been given sufficient attention. CUI Gang (2009) mentioned that the English Curriculum Standard (experimental) required high school students to "briefly introduce the culture of the motherland in English" and "have a strong consciousness of motherland and international vision" (p. 88). However, this goal does not continue at the university level. So we should regard the China culture as a part of teaching in College English syllabus, so as to greatly lessen the Chinese culture aphasia in college English teaching and meet the needs of China's economic development and international communication.

Secondly, college English textbooks are lacking the necessary contents of Chinese culture. The current college English textbooks have been fully integrated into the culture of English-speaking countries but not Chinese culture. Only the New Core College English Reading textbook provides reading material related to Chinese culture in each unit and still it does not meet the actual demand of college students. In fact, audio-visual teaching materials can be also a good means for imparting Chinese culture. Most Chinese cultural content can be covered in listening and speaking classes. Thus, modernizing the audio-visual textbooks and materials could significantly improve the teaching of Chinese cultural topics in college English teaching.

What is more, it is also essential to improve the Chinese cultural quality of college English teachers. In essence, the ultimate goal of college English teaching is intended for intercultural communication, which means college English teachers should be both bilingual and bicultural. Therefore, teachers' Chinese cultural literacy is a vital link in college English teaching, which requires teachers to have not only a good command of English language, but also Chinese culture knowledge. Admittedly, college English teachers highly recognize the importance and necessity of Chinese culture education in college English teaching. The reality is that most college English teachers "....grew up in the examination-oriented educational environment, whose Chinese cultural literacy is very insufficient, despite a good command of English language" (XU, 2009, p. 235). Therefore, it is urgent to improve the college English teachers' Chinese cultural quality, which is the indispensable guarantee for the implantation of Chinese culture in college English teaching.

Last but not the least, reforms should be made in preparing students for English exams. Nowadays, college English teaching is often focused on preparing students to pass a standardized test, such as the CET-4/6, rather than gain cultural fluency. Needless to say, with the certificate of CET-4 (or 6), university graduates are more likely to find a decent job. Under this pressure as well as the limited time for teaching college English, teachers are often forced to abandon the content of teaching Chinese culture and be focused on English language skills training. According to the investigation conducted in Beijing University of Aeronautics and Astronautics by YANG Chun-li and HE Yu-yin (2010), college English teachers all consider that "it is necessary to implant Chinese culture in College English teaching" (p. 203). It is a frequently employed method to lecture on some interesting topics of Chinese culture in college English classroom teaching. Therefore, how to correctly guide and make full use of college English classroom teaching to implant Chinese culture is worth being considered by college English teachers. 


\section{Conclusion}

In conclusion, with the realization of globalization, intercultural communication has become increasingly commonplace. However, at the same time the phenomenon that the absence of Chinese culture in intercultural exchanges has been noticed by more and more Chinese researchers. The major reason is due to the lack of Chinese culture in college English education. In order to ensure a successful intercultural communication, China needs to introduce its own culture to the outside world. Consequently, college English teaching is bound to shoulder the responsibility to spread Chinese culture. To avoid Chinese culture aphasia, attention must be paid to all aspects of English teaching at the university level. What is more important, college English teachers should improve their own Chinese cultural quality, give up the exam-oriented teaching practice, and introduce Chinese culture with consciousness. By so doing, universities and colleges can cultivate qualified graduates who can perform intercultural communication work.

\section{References}

CHEN, Z. A., LI, L., \& LIU, C. Y. (2005). Intercultual communication from theory to practice. Chongqing: Chongqing University Press.

CONG, C. (2000, October 19). Chinese culture aphasia: Defect in China's English education. Guang Ming Daily.

CUI, G. (2009). Permeation of Chinese culture in college English teaching. China University Teaching, 03, 86-89.

Hall, E. T. (1977). Beyond culture. Garden City, New York: Anchor.

JIA, J. N. (2015). Absence of national culture in foreign language teaching and intercultural communication competence training of college students in China frontier minority areas. English Language Teaching, 04, 52-56.

Kramsch, C. (2000). Language and culture. Shanghai: Shanghai Foreign Language Education Press.

MAO, J. H. (2014). The problem of Chinese culture aphasia in college English teaching and its countermeasures-A case study of non-English majors in a local university. Journal of Tianzhong, 06, 135-137.

Samovar, L. A., \& Porter, R. E. (2007). Intercultural communication: A reader (10th ed.). Shanghai: Shanghai Foreign Language Education Press.

Samovar, L. A., Porter, R. E., \& Stefani, L. A. (1998). Communication between cultures (3rd ed.). Belmont: Wadsworth Publishing Company.

The Higher Education Division of Ministry of Education. (2007). College English curriculum requirements. Shanghai: Shanghai Foreign Language Education Press.

WANG, J., FU, R., WANG, H., \& ZHAO, Y. R. (2016). Research on the lack of native culture input in college English teaching. Education Modernization, 10, 182-183, 186.

WU, L. Q. (2006, October 20). Reflections on the phenomenon of native culture "Aphasia". Guang Ming Daily.

XU, C. Y. (2009). Conceptions of the introduction of Chinese culture into college English teaching. Hebei Academic Journal, 01, 233-236.

YANG, C. L., \& HE, Y. Y. (2010). An investigation on the perception of Chinese culture teaching in college English teaching-A case study of Beijing University of Aeronautics and Astronautics. College English, 07, 202-204.

ZHANG, W. M., \& ZHU, H. M. (2002). Chinese culture in college English teaching. Research Education Tsinghua University (Supplementary issue), 01, 34-40. 


\section{Appendix}

\section{涉及中国文化的英语表达测试}

请认真填写下面的个人资料,然后请用英语表达出下列具有中国文化特色的内容,要求独立完成,时间 15 分钟。

姓名 年龄 性别__行政班号

来自于省(市、县、镇等) 中学;英语成绩:高考 ,四级

一. 食物: 请将下列十种中国常见食品用英语表达出来。

1.油条 2.豆腐

3.咸菜 4. 包子

5.麻花 6. 馄饨

7.煎饼果子 8. 饺子

请用英语写出以下五种常见的中国菜有。

1.鱼香肉丝

2.糖醋里脊

3.麻辣豆腐

4. 宫爆鸡丁

5.东坡肘子

二. 民俗：请用英语介绍即将到来的中秋节以及与其相关的庆祝活动(例如：中秋节, 赏月，月饼，合家团圆等)。

三. 历史名胜古迹：请用英语介绍一处中国的名胜古迹。 